\title{
Analisis Perubahan Penggunaan Lahan di Kawasan Perdesaan Eks Transmigrasi Kecamatan Wasile Kabupaten Halmahera Timur
}

\author{
Muchlis Husin, Yori Herwangi \\ Departement Teknik Arsitektur dan Perencanaan/Magister Perencanaan Wilayah dan Kota/ Universitas Gadjah Mada, \\ ulichmobon@gmail.com
}

INFO ARTIKEL

Riwayat Artikel:

Diterima: 02 -07-2018

Disetujui: 28-08-2018

\section{Kata Kunci:}

Penggunaan Lahan Geographic Information System

Overlay

Desa eks-Transmigrasi

\section{A. LATAR BELAKANG}

Penggunaan lahan dalam suatu wilayah merupakan suatu hal yang dinamis, sehingga perubahan penggunaan lahan selalu dijadikan salah satu indikator untuk melihat perkembangan suatu wilayah[1]. Perubahan penggunaan lahan dipicu oleh berbagai faktor yang saling berkaitan antara satu dengan lainnya[3], sehingga setiap bentuk perubahan penggunaan lahan akan berpotensi mempengaruhi penggunaan lahan lain disekitarnya. Oleh karenanya diperlukan pengkajian terkait perubahan penggunaan lahan dan peruntukannya untuk mengetahui sejauh mana tingkat perkembangan (fisik) yang nantinya sangat berguna utuk rencana pengembangan kedepannya[5].

\section{ABSTRAK}

Abstrak: Kawasan perdesaan Cemara Jaya dan Batu Raja merupakan salah satu kawasan perdesaan eks transmigrasi di Kabupaten Halmahera Timur, Provinsi Maluku Utara yang saat ini telah berkembang pesat, baik dari aspek sosial ekonomi maupun perkembangan fisik. Berbagai perkembangan tersebut menyebabkan meningkatnya perubahan penggunaan lahan, terutama perubahan dari lahan non produktif menjadi lahan produktif. Untuk itu diperlukan analisis terkait penggunaan lahan untuk menggambarkan dinamika perubahan yang terjadi. Analisis yang digunakan adalah analisis overlay yang dilakukan secara multi periode yakni tahun 1982, 1990, 2000, 2010, dan 2017. Hasil penelitian ini menunjukkan adanya perubahan penggunaan lahan di kawasan perdesaan Cemara Jaya dan Batu Raja dari penggunaan lahan yang didominasi hutan menjadi penggunaan lahan yang didominasi sawah.

Abstract: The rural area of Cemara Jaya and Batu Raja is one of the ex-transmigration village in Halmahera Timur Regency of Maluku Utara Province which is currently developing rapidly, both from the socio-economic and physical development aspects. These developments lead to increased changes in land use, especially changes from non-productive land to productive land. For this reason, an analysis related to land use is needed to illustrate the dynamics of the changes that occur. The analysis used was an overlay analysis carried out in multi periods which are 1982, 1990,2000,2010, and 2017. The results of this study indicate a change in land use in the rural area of Cemara Jaya and Batu Raja from forest-dominated land use to rice fields-dominated land use.

Permukiman transmigrasi yang terletak di kawasan perdesaan Cemara Jaya dan Desa Batu Raja merupakan satu kesatuan dari Kawasan Transmigrasi di Kecamatan Wasile yang terdiri dari enam Satuan Permukiman (SP). Permukiman transmigrasi Wasile mempunyai pola usaha pertanian yang artinya bentuk pola transmigasi dengan kegiatan pertanian tanaman pangan sebagai usaha utama bagi masyarakat transmigran. Dasar pelaksanaan program transmigrasi di Kacamatan Wasile Kabupaten Halmahera Timur, Provinsi Maluku Utara (saat itu merupakan Kabupaten Halmahera Tengah, Provinsi Maluku) atas dasar kerjasama dari Menteri Tenaga Kerja dan Transmigrasi, Menteri Pertanian, Gubernur Provinsi Maluku serta Bupati Kabupaten Halmahera Tengah. 
Sebagaimana tahapan yang direncanakan, kegiatan diawali dengan persiapan lokasi tranmigrasi pada tahun 1980. Persiapan tersebut berlangsung selama dua tahun dengan kegiatan pembukaan lahan lokasi permukiman, pembangunan rumah transmigrasi serta pembangunan sarana/prasana. Pasca tahapan pembangunan dan penyiapan lokasi, dilanjutkan dengan penempatan warga transmigrasi yang dilakukan dalam tiga tahap untuk tiga Satuan Permukiman yang dilakukan pada tahun 1982 dengan warga transmigran berasal dari Provinsi Jawa Tengah dan Jawa Timur dan sebagian warga lokal. Hingga saat ini masing-masing Satuan Permukiman di Kawasan Transmigrasi Kecamatan Wasile ini telah menjadi desa defenitif. Khususnya untuk SP-2 hingga tahun 2017 telah menjadi dua desa yaitu Desa Cemara Jaya dan Desa Cemara jaya yang saat itu statusnya menjadi Ibukota Kecamatan Wasile. Untuk lebih jelasnya terkait dengan letak dan kondisinya dapat diuraikan pada bagian selanjutnya.

Sebagai salah satu strategi pengembangan wilayah baru melalui pembangunan kawasan fungsional, pembukaan kawasan transmigrasi diharapkan mampu memberikan dampak positif terutama untuk wilayah yang dijadikan lokasi transmigrasi[6]. Adanya pelaksanaan program trasnmigrasi di wilayah ini memberikan dampak yang besar pada penggunaan lahan. Teruma pada lahan-lahan yang saat itu tidak produktif menjadi lahan-lahan produktif, yang diolah oleh warga transmigran sebagai lahan usaha, yang tentunya memberikan pengaruh yang sangat signifikan untuk pembangunan ekonomi lokal[6], [7]. Berdasarkan data pengunaan lahan, lahan pertanian khususnya pada lahan-lahan sawah setiap tahunnya terus meningkat dengan rata-rata kenaikan sebesar 30 Ha per tahun[2]. Meningkatnya lahan pertanian tersebut berdampak pada peningkatan perekonomi penduduk[4] sehingga intensitas pembangunan yang dilakukan oleh warga juga semakin meningkat. Hal tersebut mengakibatkan, peningkatan luas lahan-lahan terbangun juga terus meningkat.

Selain itu, dengan adanya rencana pemerintah daerah untuk menjadikan desa eks transmigrasi inii sebagai calon Ibukota Rencana Daerah Otonomi Baru Kabupaten Wasile, semakin mendorong adanya peningkatan penggunaan lahan untuk lahan-lahan terbangun. Sebab banyak penduduk dari luar kawasan perdeaan eks transmigrasi ini mula berdatangan untuk mencari lahan-lahan yang menurut mereka strategis untuk nantinya dijadikan sebagai tempat tinggal dan tempat usaha. Sehingga diharapkan meningkatnya kebutuhan lahan untuk permukiman dan kegiatan usaha lainnya tidak mengancam keberadaan lahan-lahan pertanian yang saat ini merupakan salah satu lumbung pangan di Provinsi Maluku Utara[8]. Segingga untuk meminimalisir benturan akan kedua kepentingan tersebut dibutukan ketepatan dalam penyusunan perencanaan penggunaan lahan kedepannya.

Oleh sebab itu, diperlukan suatu analisis terkait perubahan penggunaan lahan di kawasan perdesan eks transmigrasi ini dengan pendekatan yang tetap untuk mengetahui dan mengoptimalkan perkembangan yang kedepannya akan terus meningkat. Untuk menjawab hal tersebut, penelitian ini berupaya untuk menganalisis perubahan pengggunaan lahan secara spasial dengan dimensi multi temporer menggunakan Geographic Information System.

Tujuan dari penelitian ini adalah untuk mengetahui perubahan penggunaan lahan di Kecamatan Wasile dari tahun 1982 sampai tahun 2017.

\section{B. METODE PENELITIAN}

Secara geografis, kawasan perdesaan ini terletak antara 128 o6' oo" BT dan 1 o6'oo" LU hingga 128 o9' oo" dan 13 ' o5" LU. Kedua desa ini memilki luas wilayah $\pm 2.344,46$ Ha, yang meliputi luas wilayah Desa Cemara sebesar 1.005,26 Ha dan luas wilayah Desa Batu Raja sebesar 1.339,20 Ha. Kedua desa ini pada awalnya hanya merupakan satu wilayah administrasi desa yakni Desa Cemara Jaya. Pada tahun 2005 cakupan wilayahnya kemudian dimekarkan menjadi dua desa, sehingga menjadi Desa Cemara Jaya dan Desa Batu Raja.

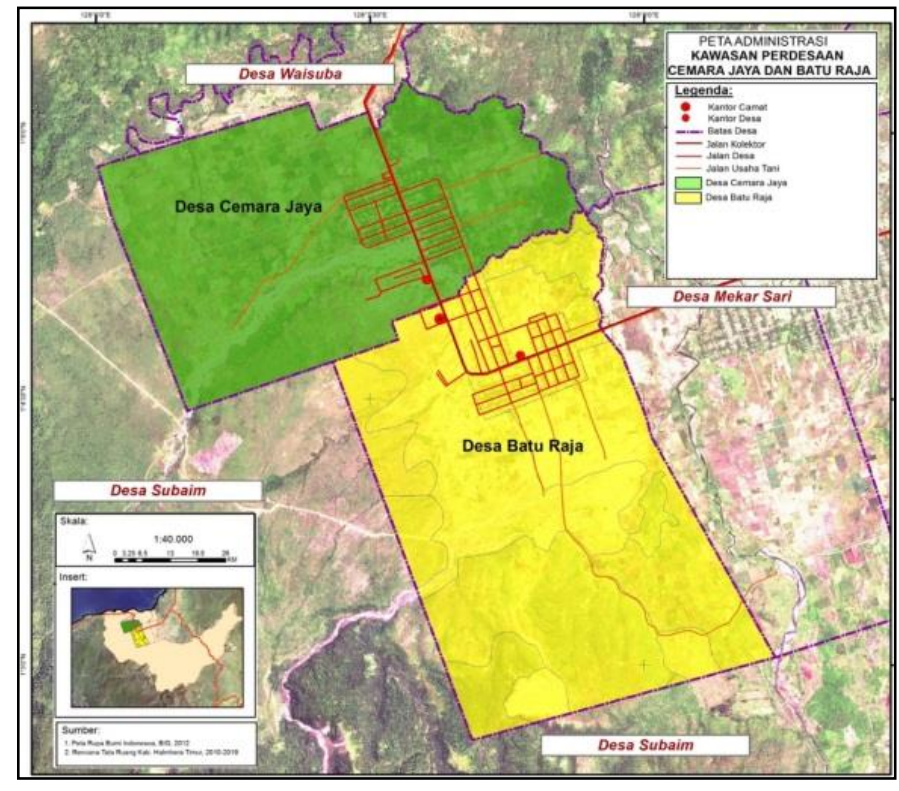

Gambar 1. Peta Desa Cemara Jaya dan Desa Batu Raja (Penulis, 2018)

Untuk mengetahui tingkat perubahan penggunaan lahan, dilakukan analisis terhadap kondisi fisik menggunakan analisis spasial dengan teknik overlay secara time series[9]. Analisis overlay merupakan salah satu teknik analisis yang dilakukan dengan bantuan software pengolahan data spasial. Teknik analisis ini bertujuan untuk melihat perkembangan penggunaan lahan sejak awal terbentuknya kawasan transmigrasi (tahun 1982) sampai dengan tahun 2017 yang dilakukan 
secara temporer karena kajian perkembangan ini tidak terlepas dari fenomena penggunaan lahan yang terus berubah tiap periode waktunya. Sehingga hasil yang didapat dari analisis ini adalah luasan penggunaan lahan pada masing-masing periode amatan dan kecenderungan pola perkembangan kegiatan[10].

\section{HASIL DAN PEMBAHASAN}

Analisis spasial ini dimaksud untuk mengetahi perkembangan fisik kawasan perdesaan Cemara Jaya dan Batu Raja melalui pengamatan perubahan guna lahan yang terjadi pada periode tahun 1982-2017. Dalam pembahasannya pengamatan perubahan guna lahan ini dibagi dalam beberapa periode waktu dengan tujuan untuk lebih memudahkan pengamatan prubahannya yakni dari periode tahun 1982, periode 1990, periode 2000, periode 2010 dan periode tahun 2017. Berikut adalah statistik luas penggunaan lahan di kawasan perdesaan Cemara Jaya dan Batu Raja berdasarka perhitungan GIS untuk periode tahun 1982, 1990,2000, 2010 dan 2017.

Table 2. Luas Penggunaan Lahan Per Periode

\begin{tabular}{|c|c|c|c|c|c|}
\hline \multirow{2}{*}{$\begin{array}{c}\text { Penggunaan } \\
\text { Lahan }\end{array}$} & \multicolumn{5}{|c|}{ Luas (Ha) } \\
\hline & 1982 & 1990 & 2000 & 2010 & 2017 \\
\hline Pekarangan & 96.00 & 101.48 & 104.65 & 154.98 & 148.69 \\
\hline Permukiman & 97.16 & 102.70 & 107.56 & 168.03 & 169.64 \\
\hline Pendidikan & 1.07 & 2.73 & 4.67 & 7.80 & 12.47 \\
\hline Kesehatan & 0.13 & 0.47 & 0.68 & 1.54 & 2.04 \\
\hline Perdagangan & 0.00 & 0.26 & 0.47 & 2.07 & 7.22 \\
\hline Sawah & 0.00 & 136.43 & 256.87 & 549.67 & 843.08 \\
\hline Hutan & 952.64 & 852.40 & 808.59 & 547.55 & 532.08 \\
\hline DAS & 65.47 & 65.47 & 65.47 & 65.47 & 65.47 \\
\hline $\begin{array}{l}\text { Kebun } \\
\text { Campuran }\end{array}$ & 700.09 & 666.14 & 601.08 & 524.96 & 228.66 \\
\hline $\begin{array}{l}\text { Semak } \\
\text { Belukar }\end{array}$ & 503.02 & 492.41 & 473.12 & 419.31 & 408.43 \\
\hline Tambang & 0.00 & 0.00 & 0.00 & 31.29 & 45.69 \\
\hline Perkantoran & 0.00 & 0.57 & 1.06 & 1.90 & 4.80 \\
\hline
\end{tabular}

Sumber: Penulis, 2018

Dari hasil analisis tersebut diatas dapat diambil sebuah pengertian bahwa dinamika perubahan penggunaan lahan yang terjadi pada setiap jenis lahan yaitu rata-rata terjadi penambahan luasan atau penguragan luasan, kecuali untuk jenis penggunaan lahan DAS yang tidak mengalami perubahan pada setiap periodenya. Peningkatan luas penggunaan lahan tertinggi terjadi pada jenis penggunaan lahan sawah, sedangkan jenis penggunaan lahan yang mengalami pengurangan secara signifikan terjadi pada lahan kebun campuran dan kawasan hutan. Untuk lebih jelas terkait dengan penggunaan lahan pada tiap periode, diuraikan sebagai berikut:

\section{Penggunaan Lahan Periode Tahun 1982}

Sebagai kawasan perdesaan transmigrasi yang mulai ditempati pada tahun 1982, kondisi penggunaan lahan pada awal periode ini sangat erat kaitannya dengan rencana alokasi pemanfaatan lahan yang telah ditetapkan pada saat perencanaan. Dimana masingmasing kepala keluarga mendapatkan jatah lahan seluas 2 Ha yang dibangi dalam lahan pekarangan seluar 0,5 Ha. Lahan Usaha I seluas $1 \mathrm{Ha}$, dan Lahan Usaha II seluas $1 \mathrm{Ha}$. Namun pada pepriode ini lahan-lahan usaha tersebut pada masih berupa kebun campurann karena pemerintah masih menyiapkan lahan-lahan tersebut untuk dijadikan lahan persawahan.

Penggunaan lahan pada periode ini secara keseluruhan digolongkan dalam 8 jenis penggunaan lahan yaitu lahan pekarangan seluas $96 \mathrm{Ha}$ atau 4,14\%, permukiman seluas $1,16 \mathrm{Ha}$ atau $0,05 \%$, fasilitas pendidikan seluas 1,07 $\mathrm{Ha}$ atau $0,05 \%$, fasilitas kesehatan seluas 0,13 Ha atau 0,01\%, kawasan hutan seluas 950,64 Ha atau 41,07 \%, DAS seluas 56,47 Ha atau 2,82 \%, lahan kebun campuran seluas 700,09 Ha atau 30,18 Ha, dan lahan semak belukar seluas 503,02 Ha atau $21,69 \%$.

\section{Penggunaan Lahan Periode Tahun 1990}

Penggunaan lahan pada periode ini terjadi penambahan tiga jenis penggunaan lahan baru berupa lahan sawah, lahan fasilitas perdagangan dan fasilitas perkantoran. Khusus pada penambahan lahan persawahan merupakan akibat dari pembukaan lahanlahan usaha-1 yang dilakukan oleh pemerintah yang kemudian diserahkan sebagai aset para warga transmigran. Akan tetapi pada periode ini lahan sawah yang selesai disiapkan baru sebatas pada lahan usaha-1 Desa Cemara Jaya. Sedangkan untuk jenis penggunaan lahan perkantoran dan perdagangan merupakan akibat dari adanya pemindahan ibukota Kecamatan Wasile ke kawasan perdesaan transmigrasi ini pada tahun 1988 sehingga pemerintah memanfaatkan lahan untuk pembangunan kedua fasilitas tersebut. Sehingga secara keseluruha penggunaan lahan pada periode ini adalah penggunaan lahan untuk pekarangan seluas 101,48 Ha atau $4,38 \%$, permukiman seluas $1,22 \mathrm{Ha}$ atau $0,05 \%$, pendidikan seluas 2,73 Ha atau 0,12\%, kesehatan seluas $0,42 \mathrm{Ha}$ atau $0,02 \%$, perdagangan seluas 0,26 ataus 0,01\%, perkantoran seluas $0,57 \mathrm{Ha}$ atau $0,02 \%$, sawah seluas 136,43 Ha atau $5,88 \%$, hutan seluas 852,40 Ha atau 36,75 \%, DAS seluas 56,47 Ha atau 2,82 \%, kebun campuran seluas 666,14 $\mathrm{Ha}$ atau 28,72 $\mathrm{Ha}$, dan lahan semak belukar seluas 492,41 Ha atau 21,23\%.

\section{Penggunaan Lahan Periode Tahun 2000}

Perkembangan penggunaan lahan pada periode ini secara keseluruhan terlihat mulai ada peningkatan yang signifikan setelah lahan-lahan sawah dan jaringan irigasi baik di lahan usaha-1 Desa Desa Cemara Jaya dan Desa Batu Raja telah selesai disiapkan dan telah dikelolah oleh warga. Dampak dari penyiapan lahan-lahan sawah tersebut memberikikan pengaruh terhadap penurunan 
luasan pada jenis penggunaan lahan kebun campuran, semak belukar dan kawasan hutan.

Secara keseluruhan penggunaan lahan periode ini adalah lahan pekarangan seluas $104,56 \mathrm{Ha}$ atau 4,51\%, permukiman seluas 2,91 $\mathrm{Ha}$ atau $0,13 \%$, pendidikan seluas 4,67 $\mathrm{Ha}$ atau 0,20 \%, kesehatan seluas 0,68 Ha atau 0,03 \%, perkantoran seluas 1,06 $\mathrm{Ha}$ atau 0,05 $\mathrm{Ha}$, sawah seluas 256,87 atau 11,07 \%, hutan seluas 808,59 Ha atau 34,86\%, DAS seluas 56,47 Ha atau 2,82 \%, kebun campuran seluas 601,08 $\mathrm{Ha}$ atau 25,91 Ha, dan lahan semak belukar seluas 473,12 Ha atau 20,40 \%.

\section{Penggunaan Lahan Periode Tahun 2010}

Penggunaan lahan pada periode ini secara umum terlihat terus mengalami perkembangan terutama pada jenis penggunaan lahan-lahan pertanian. Meningkatnya luasan lahan pertanian tersebut mengindikasikan bahwa tingkat produktivitas penduduk khusunya pada sektor pertanian terus mengalami peningkatan. Dibanding dengan periode sebelumnya, luas lahan pertanian pada periode ini mengalami peningkatan sebesar 292,80 Ha atau 30,78 \%. Kondisi ini disebabkan adanya peningkatan kebutuhan lahan untuk kegiatan pertanian khususnya untuk lahan sawah irigasi. Sehingga lahanlahan usaha (Lahan Usaha-2) yang sebelumnya dimanfaatkan sebagai kebun campuran kemudian dikonversi menjadi lahan sawah irigasi. Konversi lahanlahan usaha (Lahan Usaha-2) sebagai lahan sawah tersebut umumnya dilakukan oleh pemerintah daerah melalui Program Pencetakan Sawah Baru yang dimulai pada tahun 2007.

Selain itu, pada periode ini juga mulai terlihat adanya peningkatan luasan lahan permukiman dan lahan fasilitas pelayanan umum. Meningkatnya luas lahan permukiman dan lahan pekarangan ini tentu merupakan konsekuensi dari adanya peningkatan jumlah penduduk dan kemampuan ekonomi yang mengakibatkan semakin tingginya kebutuhan lahan untuk pemenuhan tempat hunian baru serta untuk kegiatan-kegiatan yang produktif. Pembangunan permukiman-permukiman baru tersebut dilakukan oleh warga transmigran serta sebagian warga pendatang dari daerah lain yang ingin menetap di kawasan perdesaan ini. Sehingga pada periode ini terjadi peningkatan pada luas lahan permukiman sebesar 10,13 Ha dan pada lahan pekarangan sebesar 30,33 Ha. Sedangkan untuk lahanlahan yang diperuntukan untuk pembangunan fasilitas pelayanan dasar meningkat sebesar 5,58 Ha.

Kondisi tersebut mengakibatkan secara keseluruhan penggunaan lahan periode ini adalah lahan pekarangan seluas 145,98 Ha, permukiman seluas 13,05 Ha, fasilitas pendidikan seluas 7,80 $\mathrm{Ha}$, fasilitas kesehatan seluas 1,54 $\mathrm{Ha}$, fasilitas perkantoran seluas 1,90 $\mathrm{Ha}$, fasilitas perdagangan seluas 2,07 $\mathrm{Ha}$, sawah seluas 549,67 $\mathrm{Ha}$, hutan seluas 547,55 Ha, DAS seluas 56,47 Ha, kebun campuran seluas 524,96 Ha, lahan semak belukar seluas
419,31 Ha dan lahan kegiatan pertambangan seluas 31,29 Ha.

\section{Penggunaan Lahan Periode Tahun 2017}

Penggunaan lahan pada periode ini secara keseluruhan masih memiliki kesamaan dengan periode sebelumnya dimana dinamika perkembangan penggunaan lahannya masih didominasi oleh penggunana lahan sawah dengan peningkatan sebesar 293,41 Ha pada tahun 2017. Namun terdapat sedikit perbedaan dengan periode sebelumnya dimana terdapat peningkatan luas lahan khususnya pada lahan-lahan terbangun untuk mewadahi kegiatan-kegiatan penduduk yang terus berkembang terutama pada kegiatan non pertanian yakni sebesar 20,95 Ha. Hal tersebut dipengaruhi oleh adanya peningkatan migrasi masuk dari penduduk sekitar yang mau mencari nafkah di kawasan perdesaan eks transmigrasi ini sebagai akibat dari meningkatnya aksesibilitas serta ketersediaan fasilitas pelayanan publik sebagai daya tarik yang dimiliki.

Kondisi tersebut mengakibatkan penggunaan lahan secara keseluruhan pada periode tahun 2017 yaitu lahan pekarangan seluas $148,69 \mathrm{Ha}$, permukiman seluas 20,95 $\mathrm{Ha}$, fasilitas pendidikan seluas 12,47 $\mathrm{Ha}$, fasilitas kesehatan seluas 2,04 Ha, fasilitas perkantoran seluas 4,80 Ha, fasilitas perdagangan dan jasa seluas 7,22 $\mathrm{Ha}$, sawah seluas 843,o8, hutan seluas 532,08 Ha, DAS seluas 56,47 Ha, kebun campuran seluas 228,66 Ha, semak belukar seluas 408,43 Ha dan lahan kegiatan pertambangan seluas 45,69 Ha.

Secara rinci penggunaan lahan dari periode 1982 hingga periode 2017 dapat dilihat pada gambar berikut.

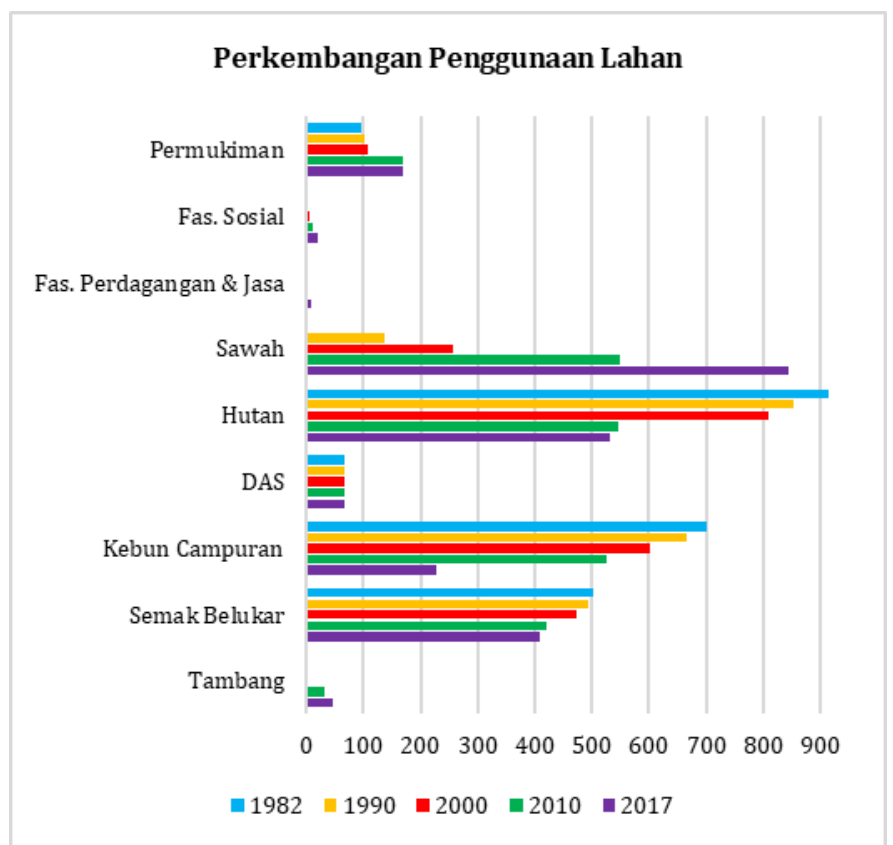

Gambar 2. Perbandingan Penggunaan Lahan Di Kawasan Peresaan Cemara Jaya dan Batu Raja, Tahun 1982-2017 (Penulis, 2018)

Mencermati penggunaan lahan pada Kawasan Perdesaan Cemara Jaya dan Batu Raja tahun sejak 1982 
hingga 2017 sebagaimana yang telah diuraikan diatas, pada umumnya terlihat kecenderungan penggunaan lahan yang terjadi yakni perubahan penggunaan lahan dari lahan yang kurang prodktif ke lahan-lahan yang lebih produktif mengikuti tingkat kebutuhan kegiatan masyarakat.
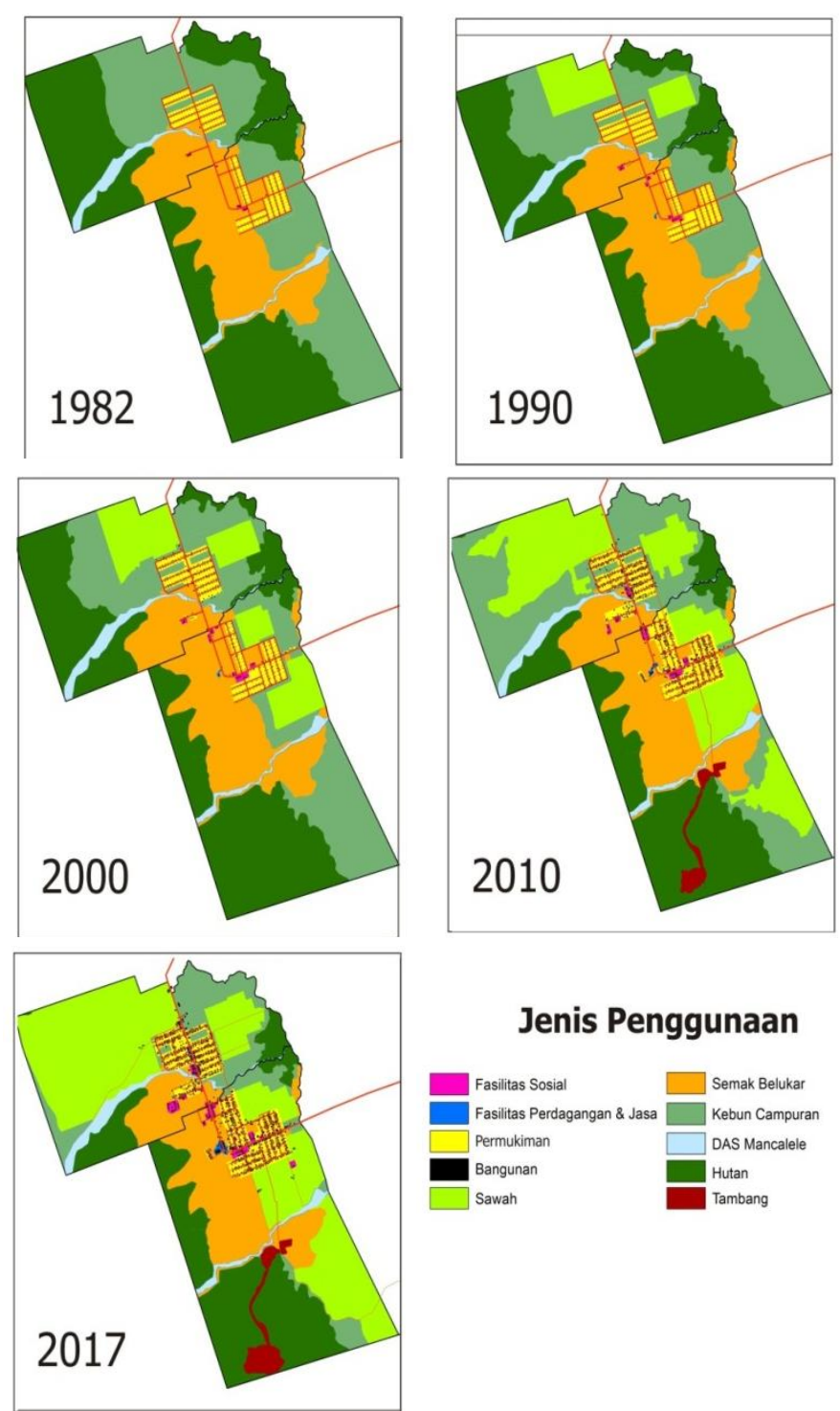

\section{Jenis Penggunaan}

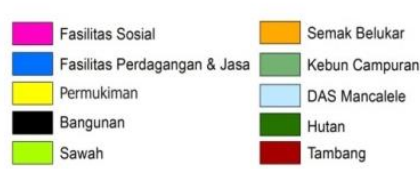

Gambar 3. Peta Penggunaan Lahan Kawasan Perdesaan Cemara Jaya dan Batu Raja Periode 1882, 1990, 2000, 2010 dan 20017 (Penulis, 2018)

Disamping itu, perubahan penggunaan lahan untuk pekarangan, permukiman dan penyediaan fasilitas umum juga terus meningkat tiap tahunnya. Dalam kurun waktu 35 tahun, secara keseluruhan lahan terbangun pada kawasan perdesaan ini seluas 101,80 Ha. Terus meningkatnya luas lahan terbangun ini mengindikasikan bahwa perubahan guna lahan dan kegiatan yang lebih produktif telah memberikan efek terhadap pendapatan masyarakat sehingga masyarakat mampu membangun rumah-rumah yang permanen dan lebih moderen. Selain itu, perkembangan penggunaan lahan terbangun ini juga didorong oleh kemudahan masyarakat dalam transaksi jual beli tanah serta kemudahan dalam perizinan. Sehingga hanya dengan modal suart jual beli tanpa harus menunggu sertifikat tanah masyarakat sudah dapat membangun tempat hunian mereka.

Dalam kurun waktu tahun 1982-20017, penggunaan lahan yang paling besar mengalami perubahan luasan antara lain penggunaan lahan untuk persawahan, pekarangan, pertambangan. Sebagai konsekuensi dari meningkatnya luasan ketiga jenis penggunaan lahan tersebut, terjadi penurunan luasan pada jenis lahan hutan, semak belukar dan kebun campuran yang cukup pesat .

\section{SIMPULAN DAN SARAN}

Berdasarkan hasil analisis yang telah dilakukan, dapat disimpulkan bahwa perubahan penggunaan lahan yang terus mengarah pada lahan-lahan yang dimanfaatkan untuk kegiatan-kegiatan produktif diantaranya persawahan, permukiman dan fasilitas pelayanan umum (lahan terbangun). Dalam kurun wakti 1982-2017, pengggunaan lahan yang paling banyak mengalami peningkatan terjadi pada lahan sawah dan permukiman. Peningkatan tersebut paling signifikan terjadi pata tahun 2000-2017 yakni meningkat sebebsar 706,65 Ha, dan untuk lahan permukiman paling signifikan terjadi pada tahun 2000-2010. Sedangkan lahan-lahan yang paling banyak mengalami pengurangan luasan yang signifikan antara lain kawasan hutan dan kebun campuran. Berkurangnya kedua jenis penggunaan lahan tersebut sebagai dampak dari perluasal lahan persawahan.

Sebagai saran, diperlukan adanya rencana pengaturan/pengendalian lahan terbangaun untuk membatasi perkembangan lahan-lahan permukiman dan fasilitas umum. Agar supaya keberadaan dari lahanlahan pertanian yang sangat produktif tersebut tidak habis terkonversi pada masa yang datang.

\section{UCAPAN TERIMA KASIH}

Terima kasih disampaikan kepada seluruh pihak yang terkait, terutama pemerintah daerah Kabupaten Halmahera Timur, serta totoh-tokoh masyarakat warga transmigran baik di Desa Cemara Jaya dan Desa Batu Raja atas bantuannya terkait dengan pemberian data dan informasi yang dibutuhkan dalam proses penulisan ini.

\section{DAFTAR RUJUKAN}

[1] Jayadinata, J, Tata Guna Tanah Dalam Perencanaan Perdesaan dan Perkotaan, Alumni, Bandung, 1986

[2] Pemerintah Daerah Kabupaten Halmahera Tumur, Dokumen Areal Penggunaan Lain Kabupaten Halmahera Timur, BAPPEDA HALTIM, Maba, 2017.

[3] Koestoer, R. H, Dimensi Keruangan Kota:Tteori dan Kasus, Universitas Indonesia, Jakarta

[4] Ruhimat, M, Geografi Penduduk, Penerbit Ombak, Yogyakarta

[5] Yunus, H.S, Manajemen Kota Dari Perspektif Spasial, Pustaka Pelajar, Yogyakarta 
[6] Rustiadi, E, Saefulhakim, S. Panuju, D, Perencanaan dan Pengembangan Wilayah, Yayasan Pustaka Obor Indonesia, Jakarta

[7] Junaidi, Stadia Pengembangan Wilayah Transmigrasi melalui Deman Side Stategy dan Keterkaitan Fungsional Desa Eks Transmigrasi dengan Wilayah Sekitarnya. Prosiding Forum Diskusi Perencanaan Pembangunan Kawasan Transmigrasi, Bogor, Indonnesia, h. 1-23, November 2014.

[8] Pemerintah Kabupaten Halmahera Timur, Peraturan Daerah Kabupaten Halmahera Timur Nomor 10 Tahun 2012 Tentang Rencana Tata Ruang Wilayah Kabupaten Halmahera Timur Tahun 2010-2030. BAPPEDA HALTIM, Maba, 2012.

[9] Yunus, HS. Metodologi Penelitian Wilayah Kontemporer, Pustaka Pelajar, Yogyakarta

[10]Suprajaka, Fitria M. D., "Analisis Dinamika Pemanfaatan Lahan Pertanian Di Kota dan Kabupaten Serang (Studi Kasus:Kecamatan Kramatwatu, Kaseman dan Pontang)", Jurnal Planesa, Vol 3, No. 1, h. 1-8, Mei 2012. 